\title{
Shewanella putrefaciens
}

National Cancer Institute

\section{Source}

National Cancer Institute. Shewanella putrefaciens. NCI Thesaurus. Code C86743.

A species of facultatively anaerobic, Gram negative, rod shaped bacteria assigned to the phylum Proteobacteria. This species can reduce metals including iron, manganese and uranium to produce energy. S. putrefaciens is found in marine environments and is a pathogen that can cause bacteremia, biliary tract infection, peritonitis, empyema, and various skin and soft tissue infections. 